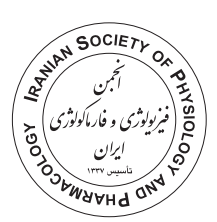

\title{
Potential therapeutic effects of some flavonoids on coronavirus disease 2019
}

\author{
Mohammad Reza Khazdair* (D)
}

Cardiovascular Diseases Research Center, Birjand University of Medical Sciences, Birjand, Iran

\section{Dear Editor,}

The novel coronavirus disease 2019 (COVID-19), or severe acute respiratory syndrome coronavirus 2 (SARSCoV-2) was first identified in China (Guan et al., 2020). This coronavirus bind to the angiotensin-converting enzyme-2 (ACE2) receptor for infection the cells by transmembrane protease serine 2 on the surface of the host cell (Hoffmann et al., 2020). Following infection by SARS-CoV-2, a large amounts of pro-inflammatory mediators such as, interferon alpha, interleukin (IL)-1b, IL-6, IL-12, IL-18, IL-33, and tumor necrosis factor $\alpha$ (TNF- $\alpha$ ) are release by immune cells (Hoffmann et al., 2020).

Various biological compounded such as of flavonoids, have therapeutic effects including, anti-inflammatory and anti-asthmatic (Khazdair et al., 2019; Kianmehr and Khazdair, 2020), antioxidant and immunomodilatory effects (Khazdair et al., 2018; Khazdair and Boskabady, 2019). The anti-SARS coronavirus effects of phenolic compounds derivate of the plants were also reported (Lin et al., 2005). Therefore, the protective effects of some flavonoids including kaempferol and quercetin on SARS-CoV-2 are suggested.

The potency of kaempferol, for blocking of 3a channel (a cation channel) which expressed in the infected cells by SARS-CoV was showed. Kaempferol $(20 \mu \mathrm{M})$ blocked more than $50 \%$ of 3 a channel in Xenopus oocyte by voltage-clamp techniques (Schwarz et al., 2014). Then, kaempferol by inhibiting of this ion channel can inhibit virus release. In an in vivo study, kaempferol $(15 \mathrm{mg} / \mathrm{kg})$ reduced pulmonary edema, permeability of pulmonary capillary and lung dry weight. Furthermore, kaempferol declined activity of myeloperoxidase, as well as the inflammatory cells in infected mice with H9N2 virus induced acute lung injury (Zhang et al., 2017). In addition, administration of kaempferol decreased production of reactive oxygen species (ROS) and malondialdehyde, reduced over production of IL- $1 b$, TNF- $\alpha$ and IL- 6 , while increased the levels of antioxidant parameters such as, superoxide dismutase activity in H9N2 infected mice (Zhang et al., 2017).

The antiviral properties of the other flavonoid, quercetin have been reported. Administration of quercetin showed therapeutic effects on SARS-CoV-2 via acting on the pro-inflammatory mediators, caspase 3 and mitogenactivated protein kinase (MAPK)-1 activity and C type lectin receptor signaling pathway (Colunga Biancatelli et al., 2020). The results of a study showed that quercetin block the binding sites on the superficial spikes of the SARS-CoV-2 and to prevent the spread of the virus (Vijayakumar et al., 2020). The ability of quercetin for inhibiting main protease -3Clpro- from MERS-CoV and SARS-CoV-2 has also been documented (Abian et al., 2020). Alteration of human genes expression encoding proteins which is targeted by SARS-Cov-2 is also attributed to quercetin. The results of a silico modelling study showed that quercetin has high affinity for binding to the interface between viral spike protein of SARS$\mathrm{CoV}-2$ and the epithelial cell ACE2 protein (Williamson and Kerimi, 2020). It has been reported that quercetin

\footnotetext{
* Corresponding author: Mohammad Reza Khazdair, khazdairMR@Bums.ac.ir Received 31 January 2021; Revised from 16 March 2021; Accepted 10 April 2021

Citation: Khazdair MR. Potential therapeutic effects of some flavonoids on coronavirus disease 2019. Physiology and Pharmacology 2021; 25: 99-101. http:// dx.doi.org/10.32598/ppj.25.2.110
} 


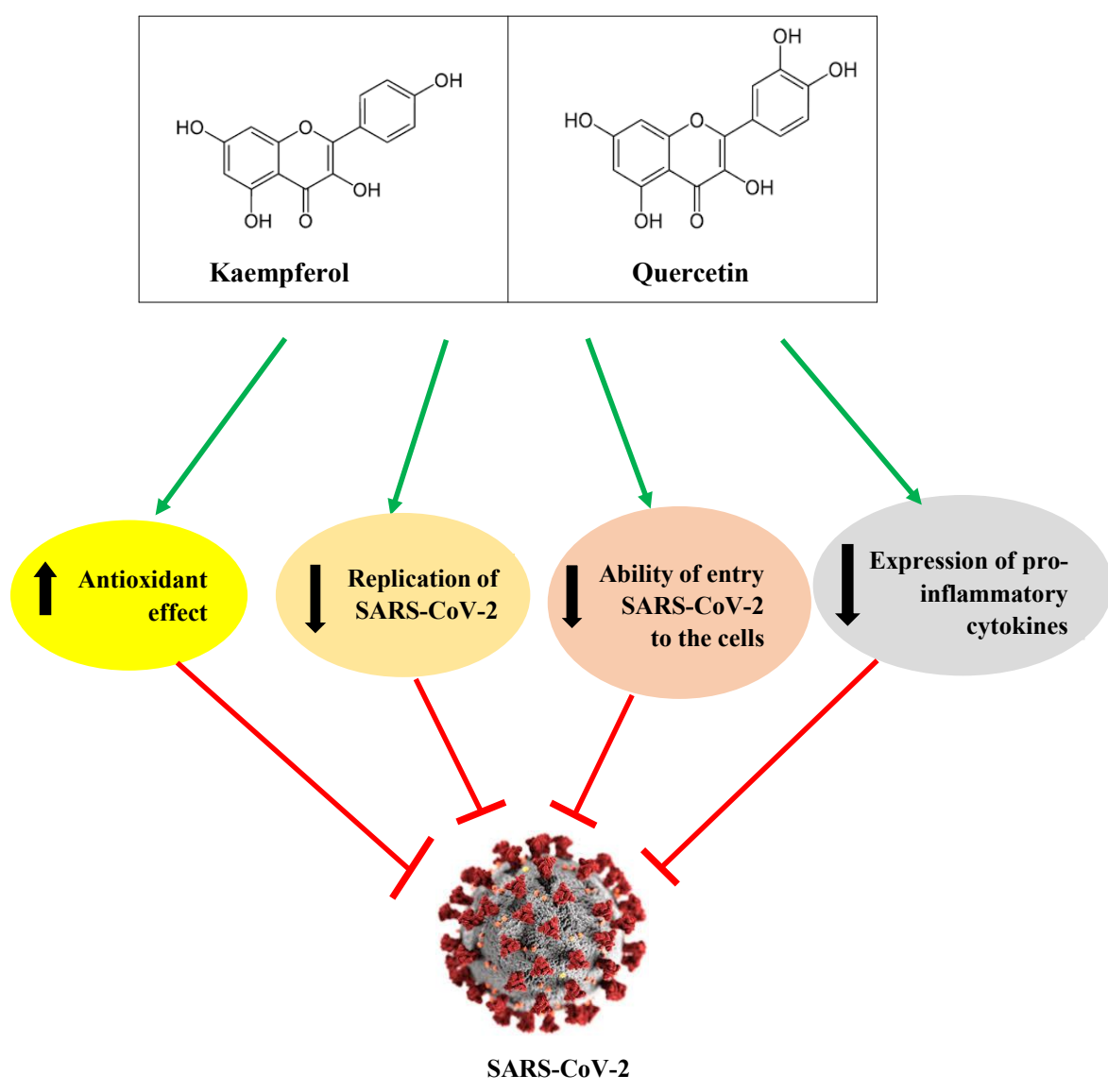

FIGURE 1. Possible therapeutic effects of flavonoids on SARS-CoV-2.

and kaempferol presented in Ficus benjamina leaves inhibited Herpes Simplex Virus 1 (Yarmolinsky et al., 2012). Quercetin along with kaempferol has been proposed to bind the proteins of SARS-CoV-2 which is involved in inflammatory responses and modulation of immune system. They could affect the expression of cyclooxygenase 2, ILs, MAPKs and alter the signaling cascade related to toll-like receptors and JAK-STAT path way (Huang et al., 2020; Wang, 2020). According scientific evidences, quercetin and kaempferol derived from Huoxiang zhengqi could inactive SARS-CoV-2. This antiviral effect is associated with inhibition of replication of SARS-CoV-2 by affecting PI3K-Akt signaling pathway (Huang et al., 2020). It is also predicted that quercetin and kaempferol have a high affinity for SARS-CoV-2, 3CL hydrolase. These two flavonoids can join to ACE2 and affect intracellular signaling cascades including BCL2, PTGS2 and caspase 3 for inhibiting viral infectious resulting from hepatitis $\mathrm{C}$, herpesvirus, measles and Epstein-Barr virus (Jimilihan, 2020). The possible therapeutic effects of flavonoids on COVID-19 is showed in Figure 1.

In conclusion, quercetin and kaempferol inhibited binding of viral spike protein of SARS-CoV-2 and the epithelial cell ACE2, protein replication of SARSCoV-2 and virus release. Quercetin and kaempferol also decreased production of ROS and pro-inflammatory cytokines, while increased the levels of antioxidant parameters. Therefore, quercetin and kaempferol may be used as a potent drug for prevention and/or treatment of SARS-CoV-2.

\section{Conflict of interest}

The author declared no conflicts of interest in this article.

\section{References}

Abian O, Ortega-Alarcon D, Jimenez-Alesanco A, Ceballos-Laita L, Vega S, Reyburn HT, et al. Structural stability of SARS-CoV-2 3CLpro and identification of quercetin as an inhibitor by experimental screening. Int J Biol Macromolecul 2020; 164: 1693-703. https://doi. 


\section{org/10.1016/j.ijbiomac.2020.07.235}

Colunga Biancatelli RM, Berrill M, Catravas JD, Marik PE. Quercetin and vitamin C: an experimental, synergistic therapy for the prevention and treatment of SARS-CoV-2 related disease (COVID-19). Front Immunol 2020; 11: 1451. https://doi.org/10.3389/fimmu.2020.01451

Guan WJ, Ni ZY, Hu Y, Liang WH, Ou CQ, He JX, et al. Clinical characteristics of coronavirus disease 2019 in China. N Eng J Med 2020; 382: 1708-20. https://doi. org/10.1056/NEJMoa2002032

Hoffmann M, Kleine-Weber H, Schroeder S, Krüger N, Herrler T, Erichsen S, et al. SARS-CoV-2 cell entry depends on ACE2 and TMPRSS2 and is blocked by a clinically proven protease inhibitor. Cell 2020; 181: 271-80. https:// doi.org/10.1016/j.cell.2020.02.052

Huang YF, Bai C, He F, Xie Y, Zhou H. Review on the potential action mechanisms of Chinese medicines in treating Coronavirus Disease 2019 (COVID-19). Pharmacol Res 2020. https://doi.org/10.1016/j.phrs.2020.104939

Jimilihan S. Study on the active components in the adjuvant treatment of novel coronavirus pneumonia (COVID-19) with Jinhua Qinggan Granules based on network pharmacology and molecular docking. J Chine Med Material 2020: 1-10.

Khazdair M, Alavinezhad A, Boskabady MH. Carvacrol ameliorates haematological parameters, oxidant/antioxidant biomarkers and pulmonary function tests in patients with sulphur mustard-induced lung disorders: A randomized double-blind clinical trial. J Clin Pharm Therap 2018; 43: 664-74. https://doi.org/10.1111/jcpt.12684

Khazdair MR, Anaeigoudari A, Kianmehr M. Anti-asthmatic effects of Portulaca oleracea and its constituents, a review. J Pharmacopunct 2019; 22: 122.

Khazdair MR, Boskabady MH. The effect of carvacrol on inflammatory mediators and respiratory symptoms in veterans exposed to sulfur mustard, a randomized, placebocontrolled trial. Resp Med 2019; 150: 21-9. https://doi. org/10.1016/j.rmed.2019.01.020
Kianmehr M, Khazdair MR. Possible therapeutic effects of Crocus sativus stigma and its petal flavonoid, kaempferol, on respiratory disorders. Pharm Biol 2020; 58: 1140-9. https://doi.org/10.1080/13880209.2020.1844762

Lin CW, Tsai FJ, Tsai CH, Lai CC, Wan L, Ho TY, et al. Anti-SARS coronavirus 3C-like protease effects of Isatis indigotica root and plant-derived phenolic compounds. Antiviral Res 2005; 68: 36-42. https://doi.org/10.1016/j. antiviral.2005.07.002

Schwarz S, Sauter D, Wang K, Zhang R, Sun B, Karioti A, et al. Kaempferol derivatives as antiviral drugs against the $3 \mathrm{a}$ channel protein of coronavirus. Planta Med 2014; 80: 177. https://doi.org/10.1055/s-0033-1360277

Vijayakumar BG, Ramesh D, Joji A, Kannan T. In silico pharmacokinetic and molecular docking studies of natural flavonoids and synthetic indole chalcones against essential proteins of SARS-CoV-2. Eur J Pharmacol 2020: 173448. https://doi.org/10.1016/j.ejphar.2020.173448

Wang L. Study on the network pharmacology and preliminary evidence of Lianhua Qingwen in the treatment of novel coronavirus (2019-nCoV). J Chin Med Material 2020; 3: $772-8$.

Williamson G, Kerimi A. Testing of natural products in clinical trials targeting the SARS-CoV-2 (Covid-19) viral spike protein-angiotensin converting enzyme-2 (ACE2) interaction. Biochem Pharmacol 2020: 114123. https://doi. org/10.1016/j.bcp.2020.114123

Yarmolinsky L, Huleihel M, Zaccai M, Ben-Shabat S. Potent antiviral flavone glycosides from Ficus benjamina leaves. Fitoterapia 2012; 83: 362-7. https://doi.org/10.1016/j. fitote.2011.11.014

Zhang R, Ai X, Duan Y, Xue M, He W, Wang C, et al. Kaempferol ameliorates H9N2 swine influenza virusinduced acute lung injury by inactivation of TLR4/MyD88mediated NF- $\kappa$ B and MAPK signaling pathways. Biomed Pharmacother 2017; 89: 660-72. https://doi.org/10.1016/j. biopha.2017.02.081 